\title{
Odraz medjezikovnih stikov v prekmurskem besedju
}

\author{
Minaela Koletnik \\ Univerza v Mariboru, Filozofska fakulteta, Koroška cesta 160, \\ SI-2000Maribor,mkoletnik@uni-mb.si
}

\begin{abstract}
Prispevek obravnava prekmursko poimenovalno besedje s področja lončarske in poljedelske dejavnosti. Gre za strokovno izrazje, ki zaradi spreminjajočega se načina življenja izginja iz aktivnega besednega zaklada govorcev. Prekmurski izrazi za lončarstvo, poljedelstvo in vse, kar je povezano s kmečkim življenjem, sicer še tvorijo bogat izvirnoslovanski substrat, vendar pa stara slovanska terminologija pri srednji generaciji govorcev hitro tone $v$ pozabo, mlajša generacija pa je sploh ne pozna več. Besedje tujega izvora v narečni lončarski in poljedelski terminologiji je zlasti germansko in romansko.
\end{abstract}

In the article the author focuses on Prekmurian vocabulary related to pottery and agricultural activities. The terminology for pottery and agricultural activities discussed in the article is disappearing from the active vocabulary of speakers, owing to the changed way of life. Prekmurian expressions describing pottery and agricultural fields and other issues of peasant life still constitute a rich part of the original Slavic substratum. However, the old Slavic terminology is rapidly vanishing among the middle generation of speakers, while the younger generation is not familiar with it at all. Terms of foreign origin in dialectal pottery and agricultural terminology are mostly German and Romance borrowings.

Ključne besede: dialektologija, prekmursko narečje, strokovna terminologija, jezikovni stik

Key words: dialectology, Prekmurje dialect, occupational terminology, language contact

\section{Uvod}

Slovenski jezik, ki se je dolga stoletja razvijal na ozemlju, kjer se stikajo slovansko, germansko in romansko jezikovno področje, se je po propadu fevdalne 
družbe začel razvijati v moderni evropski kulturni jezik, v katerem se prepletajo romanski, germanski, madžarski in splošnoslovanski elementi s podedovanim praslovanskim osnovnim besednim fondom. V panonskem prostoru se je zaradi različnih zgodovinskih okoliščin, Prekmurje s Porabjem je bilo od 11. stoletja sestavni del ogrskega kraljestva in odtrgano od drugih slovanskih pokrajin, ohranilo veliko arhaizmov, katerih del je izpričan v Brižinskih spomenikih in stari cerkveni slovanščini.

Prispevek prinaša izsledke raziskave izvirnoslovanskega in neavtohtonega besedja, prevzetega iz grško-latinskega, nemškega in madžarskega jezikovnega prostora v prekmurski strokovni (lončarstvo, poljedelstvo) terminologiji.

\section{Narečna podoba Prekmurja}

Prekmursko narečje, ki je najbolj vzhodno slovensko narečje, se govori v Prekmurju, ob zgornji Rabi v okolici Monoštra ter v nekaj vaseh ob madžarsko-avstrijski meji v Avstriji. Zaradi številnih in ostrih razdelitev Prekmurja vse do 18. stoletja so se na tem območju oblikovala tri temeljna podnarečja: severno - goričko (ob zgornji Ledavi in v Porabju), osrednje - ravensko (od Cankove prek Murske Sobote do Filoveev in Kobilja) in južno - dolinsko (vzdolž Mure). Zinka Zorko (1998: 42) ugotavlja, da se med seboj razlikujejo po mlajših prekmurskih razvojih, ki se kažejo zlasti v (1) različnih odrazih za dolgi in kratki $a$; v goričkem in ravenskem podnarečju se kratki in nenaglašeni $a$ zaokrožujeta, v dolinskem pa se pod vplivom prleškega narečja zaokrožuje dolgi $a \mathrm{v}$ o:/å:, kratki naglašeni in nenaglašeni $a$ pa ostajata odprta vokala; (2) $\mathrm{v}$ razvoju končnega $-l \mathrm{v}-o \mathrm{v}$ goričkem in ravenskem podnarečju ter $-u \mathrm{v}$ dolinskem, (3) v izgovoru zvočnika $j$, ki se v dolinskem in delu vzhodnega ravenskega podnarečja izgovarja kot $j$, sicer kot $d j, g, k$ ali $d \check{z}$. Starejši glasoslovni in oblikoslovni razvoji so dokaj enotni. ${ }^{1}$

\section{Narečno strokovno izrazje}

Narečno lončarsko in kmetijsko strokovno izrazje je, kakor velja za glavnino vseh strok, dvojno: delno gre za posebno, enopomensko besedje, ki se nanaša izključno na predmete ali opravila v zvezi z lončarsko in kmetijsko dejavnostjo, drugi del sodi v splošni besedni zaklad in ima v stroki značilnosti splošne rabe, lahko pa je tudi pomensko ali oblikovno modificirano (prim. Jež 1997: 212). Narečno strokovno izrazje je izpisano iz transkribiranih besedil in dopolnjeno z intervjujem z informanti, ki so skupaj z raziskovalko pregledali lončarsko orodje in izdelke v lončarski delavnici, jih poimenovali ter opisali njihovo izdelavo in uporabo, v predstavitvi prekmurskega poljedelskega izrazja pa je zajeto staro

\footnotetext{
${ }^{1}$ Več o tem glej pri Greenberg (1993: 465-487) in Koletnik (2008: 13-16).
} 
besedje, ki izginja in ki ga pozna le še najstarejša generacija govorcev, pa tudi sodobno besedje, ki ga je na to področje prinesla sodobna tehnika in ki se ga oprijema mlajša generacija. ${ }^{2}$

Zbrano besedje lahko glede na izvor razdelimo na neprevzeto besedje, germanizme, romanizme, madžarizme in drugo prevzeto besedje. ${ }^{3}$

3.1 Neprevzeto besedje (izbor): ${ }^{4}$ črepnja || črre:ipnja -e tudi črepn'jẹ:i ž zosoda $z a$ vodo na lončarskem vretenu, kos razbite lončene posode in kos, primerek lončarskega izdelka $\leftarrow$ izpeljanka iz podstave črep (pslovan. *čêrpъ, cslovan. črěps), znane v več slovanskih jezikih, ki izhaja iz ide. osnove s prvotnim pomenom *'nekaj odsekanega razbitega', nato pa 'lončena posoda', delati peški || 'dẹlatị 'pẹški nedov. oblikovati glineno posodo na lončarskem vretenu brez pomoči elektromotorja, delavnica || de'la:vnica -e ž prostor, ločen od ostalih prostorov $v$ hiši, $v$ katerem se izdelujejo in običajno tudi sušijo lončarski izdelki, glava || g'la:va gla'vẹ:i ž zgornja plošča na lončarskem vretenu, na kateri se oblikujejo glineni izdelki $\longleftarrow$ etimologija besede, ki je sicer splošnoslovansko razširjena, ni zadovoljivo pojasnjena; domnevno je njen prvotni pomen *'goli, tj. neoblečen del telesa', metaforični pomeni pa so 'kos, razum, zgornji del, najvažnejša osebnost, vrh', globati ven || 'vö g'lo:ubati nedov. votliti, globiti jamo, kjer se koplje glina $\leftarrow$ globsti, globem 'dolbsti' tudi globati, globam, globljem 'dolbsti, izpodjedati' je morda nastalo po metatezi (deloma naslonjeno na globok) iz pslovan. *dblbti, kar izhaja iz ide. osnove s pomenom 'kopati, dolbsti' in 'drog kot orodje za kopanje', ilovica || 'ilovica -e tudi 'ilojca -e tudi 'ilofca -e ž gnetljiva snov, ki se uporablja kot surovina v lončarstvu; glina $\leftarrow$ izpeljano iz splošnoslovanske podstave $i l$ 'ilovica, glina', kar je prvotno domnevno pomenilo *'umazana snov', *'temna snov', jesti || 'gẹski -i ž mn. odprtina za vlaganje posode $v$ peč $\leftarrow$ pslovan. *(j)ěstěja domnevno izvira iz ide. osnove s pomenom 'goreti', kamenec || 'kåmenec -nca m ozek, neloščen, zelo trden vrč z izlivom za vino in olje $\leftarrow$ izpeljanka iz splošnoslovanske podstave kamen ( $\leftarrow$ pslovan. *kamy, cslovan. kamy), ki izhaja iz ide. osnove s prvotnim pomenom 'oster', kopati || 'kọpati tudi ko'påti 'kọplen nedov. dobivati, jemati ilovico iz zemlje $\leftarrow$ pslovan. *kopäti izhaja iz ide. osnove s pomenom 'obdelovati z ostrim orodjem, rezati', kropnica \| k'ro:unpnica -e ž velika nepološčena lončena posoda brez ročajev za kuhanje svinjske krme $\leftarrow$ praslovanska osnova *kropz" 'krop, kipeča voda' je izpeljana iz *kropïti in prvotno domnevno pomeni *'kar škropi', lončar || lon'ča:r -a m izdelovalec glinene posode $\leftarrow$ izpeljanka iz južnoslovanske podstave lonec 'lonec, posoda', mesiti || 'me:isiti -in nedov. gnesti (glino) $\leftarrow$ splošnoslovansko razširjena beseda, ki izhaja iz ide. osnove s pomenom 'mešati', oblijalo || obli'jålo -a s steklasta snov za prekri-

\footnotetext{
${ }^{2}$ Zaradi prostorskih omejitev tukaj predstavljamo samo izbor besedja.

${ }^{3}$ Pri terminu, prevzetem iz tujega jezikovnega sistema, je smer izposoje ugotovljena s pomočjo slovarjev (Bezlaj I-V /1976-2007/, Skok I-III /1971-1973/, Snoj /2003/, Striedter-Temps /1963/) in drugih priročnikov.

${ }^{4}$ Etimologije izbranih besed so povzete po Bezlaju (1976-2007) in Snoju (2003).
} 
vanje lončarskih izdelkov; lošč $\leftarrow$ izpeljanka iz splošnoslovanske podstave liti, ki izhaja iz ide. osnove s pomenom 'liti, zlivati, točiti', par || 'pa:r -a m velika trebušasta lončena posoda naravne barve z nazobčanimi robovi po ploskvi za kuho perila in z odprtino z nastavkom spodaj za izpust vode $\leftarrow$ pslovan. *pârz je nomen actionis $\rightarrow$ nomen loci k *päriti, *pärišb 'delati paro', peč || 'pẹ:ič pe'či:i ž naprava za žganje lončarskih izdelkov pri visoki temperaturi $\leftarrow$ splošnoslovanska beseda, ki izhaja iz ide. osnove s prvotnim pomenom *'pečenje, kuhanje', nato pa 'mesto ali priprava, kjer se kuha ali peče', poknja || 'pọknja -e ž razpoka $v$ lončarski peči, pri kateri uhaja dim $\leftarrow$ izpeljanka iz podstave pokati 'dobivati razpoke, lomiti se' in 'tepsti, tolči' s prvotnim pomenom 'zlomiti se', 'tolči', potegniti gor \|| po'tẹ:igniti 'gọrik dov. dajati določen videz, obliko lončarskemu izdelku, sejak || silja:k -a m lončarsko orodje(mlin) za mletje glazure, barve, ki sestoji iz dveh kamnov, s kakršnimi so nekoč mleli moko, vdelanih $v$ leseno ogrodje, ki se ju poganja z batom $\leftarrow$ izpeljanka iz podstave sejati 'metati, trositi seme v zemljo', ki izhaja iz ide. osnove s prvotnim domnevnim pomenom *'tresti, stresati', smolenjak \| smolen'ja:k -a m smolnata borova polena $\leftarrow$ izpeljanka iz splošnoslovanske podstave smola, kar izhaja iz ide. osnove s pomenom 'počasi goreti, tleti', sopih || 'sọpi -ja m odprtina za zračenje na lončarski peči; oddušek $\leftarrow$ deverbativna nomina actionis iz v. *sop-ych-ati oz. sop-uch-ati k *sop-ti" *sopèšb 'pihati, puhati', kar izhaja iz ide. osnove 'pihati, dihati, spati', sušenje || sišen'jẹ: sišen'ja: s postopek, ko surova posoda po oblikovanju na lončarskem vretenu nekaj časa odleži, običajno na deskah pod stropom delavnice, da postane suha, zemlja || 'zemla -e tudi zem'lẹ:i ž gnetljiva snov, ki se uporablja kot surovina v lončarstvu, žgati || ž'gåti ž'gẹ:in nedov. $z$ močnim segrevanjem delati trdno $\leftarrow$ pslovan. *žět'l', *žëgQ 'žgati' izhaja iz ide. osnove s pomenom 'žgati'; betvo || 'betvo -a s tudi 'betef -tvi ž steblo (buče, žit) $\leftarrow$ pslovan. *bъtb̆ 'rastlina, zelišče, sadika, steblo' izhaja iz ide. osnove s prvotnim pomenom *'kar raste, uspeva', brana || b'ra:na -e ž orodje $z$ železnimi zobmi za rahljanje zemlje $\leftarrow$ splošnoslovansko razširjena beseda izhaja iz ide. osnove s pomenom 'obdelovati z ostrim orodjem', cepe || ci'pẹ:i 'ce:ipi ž mn. preprosto orodje za ročno mlačev $\leftarrow$ izpeljanka iz podstave *cépíti 'sekati, klati'; cepe so prvotno *'orodje, s katerim se cepi, tolče, ločuje zrnje od slame' (Snoj 3003: 71), čeliti || 'čeliti -in nedov. površno (o)mlatiti snop, gnoj || g'nọj gno'ja: m prostor za odlaganje gnoja in iztrebki domačih živali, pomešani steljo $\leftarrow$ splošnoslovansko razširjena beseda izhaja iz ide. osnove s pomenom 'gnitje', gumno || 'gümla -e ž prostor, kjer se navadno mlati $\leftarrow$ pslovan. *gumьnö *'prostor, kjer se mlati' izhaja iz ide. osnove s prvotnim pomenom *'prostor, kjer govedo tepta pšenico'; pšenico so včasih mlatili tako, da so jo razprostrli na trdo podlago in nanjo spustili govedo, ki je po njej hodilo toliko časa, dokler se zrnje ni ločilo od slame (Snoj 2003: 196), klepati \| kle'påti k'leplen nedov. $z$ udarci kladiva tanjšati, ostriti rezilo $\leftarrow$ pslovan. *klepát $i$ 'tolči, biti' je iz onomatopeje *klep-, ki posnema zvoke, nastale ob trku dveh (kovinskih) predmetov, kola \|| 'ko:unla 'ko:ull s mn. lesen voz, zlasti kmečki $\leftarrow$ splošnoslovansko kolo izhaja iz ide. osnove s pomenom 'vrteti se', kosa 'kọsa -e tudi ko'sẹ:i ž orodje z dolgim rezilom in dolgim ročajem za košenje 
trave, kovinski del priprave, orodja, s katerim se reže in slamoreznica, kosilnica || ko'silnica -e ž večji stroj za košenje $\leftarrow$ izpeljanka iz splošnoslovanske podstave kosa, ki izhaja iz ide. osnove s pomenom 'rezati', kozara || ko'zåra -e ž skupina desetih pokonci postavljenih rženih snopov in skupina do trideset pokonci postavljenih koruznih snopov, krma || 'krma -e ž (pokošena) trava, seno $\leftarrow$ pslovan. *krzmä verjetno izhaja iz ide. osnove in izhodiščno pomeni *'odrezan, oddeljen delež hrane', locne || loc'nẹ:i 'lo:úcni ž mn. priprava iz ovalnega obroča in vrvi, ki se uporablja za prenašanje zlasti krme in listja; krplja $\leftarrow$ mn. oblika samostalnika locen $(\leftarrow *$ *locьnъ); beseda izhaja iz ide. osnove s pomenom 'krivina, kar je ukrivljeno, upognjeno', lupati || 'lü:ipati -len nedov. odstranjevati s koruznega storža krovne liste; ličkati $\leftarrow$ splošnoslovanska beseda izhaja iz ide. osnove s pomenom 'lupiti', nat || 'na:t na'ti:i ž nadzemni deli repe, krmne pese, krompirja $\leftarrow$ domnevna pslovan. oblika *nati naj bi izhajala iz ide. osnove s pomenom 'vezati, pripeti', okapati \| o'ka:pati -len nedov. rahljati zemljo okoli rastlin in pri tem odstranjevati plevel, okopavati, orati || o'råti or'gẹ:in nedov. rahljati zemljo s plugom $\longleftarrow$ pslovan. *oräti izhaja iz ide. osnove s pomenom 'orati', oslica || 'ọslca -e ž kopica sena za čez zimo, otava || 'o:ưtava -e ž (posušena) trava druge košnje $\leftarrow$ pslovan. *otäva 'trava, ki zraste po prvi košnji' se izvaja iz pslovan. *otäviti 'ponovno se pojaviti'; beseda je tako prvotno pomenila *'(trava), ki se ponovno pojavi' (Snoj 2003: 482), plug || p'lük -ga m orodje, priprava za oranje $\leftarrow$ če je pslovan. *plügb izvirno slovanska beseda, izhaja iz pslovan. glagola *plüžiti 'vleči, plaziti', kar izhaja iz ide. osnove; beseda bi bila lahko izposojena iz pgerm., vendar nem. Pflug razlagajo kot izposojenko najverjetneje iz praslovanščine (Snoj 2003: 529), polza || 'puza -e ž del sprednjega trabja pri vozu, povreselj || pov're:isi -na $\mathrm{m}$ zvit šop slame za vezanje snopov; povreslo $\leftarrow$ pslovan. *poverslö 's čimer se kaj poveže' je izpeljanka iz *poversti', povbrzQ 'povezati', razsohe || 'råsije tudi 'råsje 'ra:seu ž mn. vile $\leftarrow$ Bezlaj (1995: 160) slovan. *őrz-socha 'veja z razcepljenim krakom' izvaja iz pslovan. *orz- 'raz' in *sochä 'veja', sečka \| 'sẹčka -e ž na nekaj centimetrov zrezana slama, zmešana s koruzinjem, jeseni tudi s travo in deteljo; rezanica $\leftarrow$ izpeljanka iz glagola seči, sečem, ki izhaja iz ide. osnove s pomenom 'sekati, rezati, trobi || tro'bi:i -i:i tudi trä'bi:ẹ -i:i ž mn. trikotni del voza, na katerega so pritrjena prednja ali zadnja kolesa, vtaknjen med podvozje in oplen; trabje, vlat || v'la:t vla'ti:i ž zgornji del rastline, ki vsebuje zrna, zlasti pri ovsu, prosu $\leftarrow$ pslovan. *vôltb izhaja iz ide. osnove s pomenom 'trava, klas, gozd'.

Neprevzeti leksemi so tudi tisti, ki so tvorjeni iz prevzetih leksemov s pomočjo domačih besedotvornih postopkov (Šekli 2005: 178; Toporišič 1992: 218). Izbor: bidrača || bid'råča -e ž okrogel ali podolgovat pekač (model) za potico $\leftarrow$ iz bidra $\leftarrow$ šaj. nem. Wider, Widerl, kuhač $\|$ ki'ja:č -a m velik trebu$\check{s}$ ast lonec za kuhanje, navadno z dulcem ter enim ali dvema ročajema $\leftarrow$ iz kuhati kuhan $\leftarrow$ stvnem. kohhōn $\leftarrow$ lat. coquere, putrica || 'pü:itrica -e ž majhna putra, namenjena za okras, olepšavo prostorov $\leftarrow$ iz putra $\leftarrow$ srvnem. puterich, buterich $\leftarrow$ domnevno rom. buttis, scentrirati $\|$ scent'rẹ:irati -an dov. z enakomernim pritiskanjem navzdol in proti sebi potiskati glino $v$ središče vrtenja $\leftarrow$ iz 
centrirati $\leftarrow$ nem. Center, Zentrum, zentrieren $\leftarrow$ lat. centrum $\leftarrow$ gr. kéntron, švunglar || švuunglar -a m spodnja plošča na lončarskem vretenu, ki se poganja $z$ nogo $\leftarrow$ iz švung $\leftarrow$ nem. Schwung; balirati $\|$ ba'lẹ:irati -an nedov. s strojem pri spravljanju pridelkov delati zvitke slame, sena $\leftarrow$ iz bala $\leftarrow$ nem. (Stroh)balle, bintljati || bint'låti bint'la:n nedov. odstranjevati pleve in primesi iz žita $\leftarrow$ iz bintelj $\leftarrow$ nem. Wind-, silaža $\|$ si'la:ža -e ž krma, kisana v silosu $\leftarrow$ iz silos $\leftarrow$ hrv. sïlos $\longleftarrow$ špan. silo $\longleftarrow$ lat. $\longleftarrow$ gr., šajbati vkup $\|$ f'küp 'ša:jbati nedov. $z$ grabljami spravljati krmo v vrste $\leftarrow$ iz šajba $\leftarrow$ nem. Scheibe, štalice \| š'tålce š'ta:lic ž $\mathrm{mn}$. hlev za svinje $\leftarrow$ iz štala $\leftarrow$ srvnem. stal, -lles, žlajdranica \| ž'låjdranca -e ž veriga za spenjanje voza $\leftarrow$ iz žlajdra $\leftarrow$ bav. avstr. Schleuder, srvnem. sluder.

3.2 Germanizmi. V zbranem besedju se pojavljajo naslednji germanizmi: $b a$ ger, bajdla, bajdlin, bajsa, blek, cigel, cota, drot, filc, flek, glazirati, glazura, graba, gratati, grunt, hakelj, kahlica, krigelj, krugla, lagev, leder, malati, pleh, ror, šajba, šalica, šerblin, šleferka, šnita, špakla, špic, šprekla, šprickati, šprigla, štancati, štancpreša, štanga, štelaž, štoplin, štuc, šurc, švunkšajba, taler, uta, vajdlin, velb, verkštat; ajdina, bala, burgula, copanj, cvek, gepelj, grinta, kramp, krumpič, lada, lanec, lunek, muntelj, paklin, praha, prigelj, pucati, puška, rigelj, rigolati, rinek, ripsa, šavfla, šinja, šker, štala, šteslin, štil, štranga, štroštok, šuber, šubgare, vaga, važa, virt, žlajf, žlajfati.

Predstavljamo izbor: bajdla || 'ba:jdla -e ž velika globoka lončena skleda $z$ dvema ročajema za mesenje kvašenega testa, pranje zelenjave, pomivanje posode ter pripravo glazur in barv v lončarstvu $\leftarrow$ domnevno bav. baidl, baidling, bajsa || 'ba:jsa -e ž najkvalitetnejša bela glina za barvanje oz. krašenje lončarskih izdelkov $\leftarrow$ nem. weiss, filc \|| 'filc -a m tudi 'filca -e ž klobučevina kot pripomoček za glajenje posode od znotraj $\longleftarrow$ nem. Filz, glazirati $\|$ gla'zẹ:irati -an nedov. prekrivati lončarske izdelke z loščem $\leftarrow$ nem. glasieren, grunt $\|$ g'rünt -a $\mathrm{m}$ barva, pridobljena iz rjavkastorumene gline za barvanje in krašenje surovih lončarskih izdelkov; podbarva $\leftarrow$ srvnem. grunt, nem. Grund, krugla || k'rugla -e ž manjši kos obdelane gline, primeren za oblikovanje na lončarskem vretenu $\leftarrow$ nem. Kugel, leder || 'lẹder -dra m usnje za vlaženje gline in potegovanje posode navzgor in navzven $\leftarrow$ nem. Leder, šajba \| 'ša:jba -e ž osnovna lončarska priprava iz zgornje in spodnje plošče, štirih stebrov in več desk, na kateri lončar oblikuje glineno posodo; lončarsko vreteno $\leftarrow$ nem. Scheibe, špregla \| šp'rẹ:jgla -e tudi šp'rẹ:jkla -e ž orodje (pripomoček) za glajenje posode od zunaj $\leftarrow$ nem. Spreitel, Spriessel, štancati \|| š'ta:ncati -an nedov. na stiskalnici serijsko oblikovati lončene predmete $\leftarrow$ nem. stanzen, štancpreša || š'ta:jncp'rẹša -e ž stiskalnica za serijsko oblikovanje lončenih predmetov $\leftarrow$ nem. Stanzpresse, verkštat || 'vẹrštat -a m lončarska delavnica v bivalnem prostoru $\leftarrow$ nem. Werksttat; ajdina || e'di:inna tudi i'di:ina -e ž kulturna rastlina z gostimi rdečkastimi ali belimi cveti v gostem socvetju ali njeno seme $\leftarrow$ star. nem. Heiden, gepelj \| 'gẹ:pl -na m priprava za vrtenje pogonske gredi, ki jo poganja vprežna živina; vitel $\leftarrow$ nem. Göpel, kebel $\|$ 'kebeu -bla m mernik (za zrnje, fižol) $\leftarrow$ pslovan. $\leftarrow$ germ., lanec || 'lånc -a m veriga za spenjanje koles voza $\leftarrow$ srvnem. lanne, lunek || 'lü:nek -a m konec osi pri vozu (kapica) z dvema vtaknjenima žebljema, ki 
preprečujeta, da kolo ne pade, zdrsne z osi $\leftarrow$ srvnem. lun, lune, muntelj $\|$ 'münteu in 'minteu -tla m držaj pri kosišču $\leftarrow$ stvnem. muntil, južno bav. Mü(n)tel, praha || p'råja -e žjeseni preorana in navadno do naslednje pomladi neposejana, neposajena njiva $\leftarrow$ srvnem. brāche, rigolati $\|$ ra'gu:lati -an nedov. rahljati zemljo $z$ (zelo) globokim prekopavanjem, oranjem $\leftarrow$ nem. rigolen, ripsa || 'ripsa -e ž rastlina, ki rumeno cvete in se njeni nadzemni deli rabijo za krmo; oljna repica $\leftarrow$ nem. Raps, šker $\|$ š'kẹ:jr -i ž orodje $\leftarrow$ stvnem. giskirri, srvnem. geschirre, štranga || št'ra:nga -e ž vrv za vpreženje živali $k$ vozu, plugu; zaprežnica $\leftarrow$ srvnem. strange, važa || 'våjža -e ž vrhnja plast zemlje z rastlinjem, zlasti s travo; ruša $\leftarrow$ srvnem. wase, stvnem. waso.

Kot je razvidno iz gradiva, segajo najstarejše nemške izposojenke $v$ prekmurščino v starovisokonemško (od 7. do 11. stoletja) oz. alpskoslovansko obdobje. $\mathrm{S}$ stališča sodobnega slovenskega knjižnega jezika so označene kot narečne (uta, vaga 'drog pri vozu'), narečne vzhodne (graba) ali žargonske (malati). Srednjevisokonemške (do 13. stoletja) in poznejše izposojenke, predvsem iz bavarske nemščine, so bile sprejete v knjižni jezik kot stilno nezaznamovane (filca, gepelj, glazirati, kramp, praha), pogovorne (špic(a)), nižje pogovorne (stelaža, šprekla, špricati, štala, štranga), narečne (krugla, lunek, rips(a), šajba 'lončarsko vreteno', važa) ali narečne vzhodne (ajdina); ena beseda (rigolati) ima terminološki in ena (lanec) časovno-frekvenčni kvalifikator, večina pa jih živi samo v narečju. Zelo stara germanska izposojenka, izpričana že v praslovanščini, je kebel, s stališča sodobnega slovenskega knjižnega jezika označena kot narečna.

3.3 Romanizmi so naslednji: blanja, kanal, kelih, kolobar, komplet, korbelj, kufer, lavor, luster, majolika, majster, mašin, model, modla, penzlin, pisker, preša, putra, servis, teglin, vaza, vrč; cima, freza, kvatre, lucerna, sirek, traktor.

Predstavljamo izbor: kolobar || kolo'ba:r -a m osnovna lončarska priprava iz zgornje in spodnje plošče, štirih stebrov in več desk, na kateri lončar oblikuje glineno posodo; lončarsko vreteno $\leftarrow$ verjetno rom., korbelj $\|$ 'kọrbeu -bla m večja pletena posoda iz lubja za nošenje ilovice iz jame $\leftarrow$ srvnem. korbe $\leftarrow$ lat. corbis, majster || 'ma:jster -tra $\mathrm{m} k$ dor ima najvišjo usposobljenost $v$ (lončarski) stroki $\leftarrow$ bav. srvnem. moister, stvnem. meistar, nem. Meister $\leftarrow$ rom. maestro $\leftarrow$ lat. magister, penzlin || 'pẹ:jnzlin -a m pripomoček iz daljših dlak za mazanje, barvanje in lepšanje lončene posode; čopič $\leftarrow$ srvnem. pensel, bensel $\leftarrow$ srlat. penicellus, klas. lat. peenicillus, putra \|| 'pü:itra -e ž lončen vrč (za vodo, vino, olje) s trebušastim telesom, ozkim in kratkim vratom ter ročajem z nastavkom za luknjico za pitje $\leftarrow$ srvnem. puterich, buterich $\leftarrow$ domnevno rom. buttis, vrč $\|$ 'vr:č -a m večja trebušasta posoda z ročajem, ožjim grlom in dulcem za nalivanje tekočin $($ vode, vina $) \leftarrow$ rom. $\leftarrow$ lat. urceus; cima $\|$ 'cina -e ž poganjek $i z$ gomoljev krompirja $v$ zimskem času $\leftarrow$ ben. it. cima $\leftarrow$ lat. cȳma $\leftarrow$ gr. $k \bar{y} m a$, freza \|f f'rẹ:za -e ž priprava z vrtečimi se rezili za prekopavanje zemlje, $k i$ se priključi traktorju; prekopalnik $\leftarrow$ frc. fraiser, fraise, lucerna \|l lu'cerna -e ž krmna rastlina s trojnatimi listi in modro vijoličastimi cveti; Medicago sativa $\leftarrow$ nem. Luzerne $\leftarrow$ frc. luzerne $\leftarrow$ lat. lūcerna, sirek $\|$ 'sirek -rka m koruzi po- 
dobna kulturna rastlina z latastim socvetjem in drobnimi semeni ali njeno seme $\leftarrow$ srlat. syricum, traktor $\|$ t'råktor -a m motorno vozilo za vleko, delo, zlasti $v$ kmetijstvu $\leftarrow$ nem. Traktor $\leftarrow$ lat. tractor.

Največ romanizmov, zlasti latinskih in nekaterih v latinščini navadnih grških izposojenk, je bilo v panonsko leksiko sprejetih prek nemščine, nekateri med njimi že v staro- in srednjevisokonemški dobi (korbelj, penzlin, preša, putra). $\mathrm{S}$ stališča sodobnega slovenskega knjižnega jezika so te besede označene kot stilno nezaznamovane (cima, lucerna, sirek, traktor, vaza, vrč), pogovorne ( $m a$ šina, preša 'stiskalnica'), narečne (blanja), narečne vzhodne (putra), nekatere pa živijo samo v narečju (kolobar 'lončarsko vreteno'). Ena beseda (freza) ima terminološki, ena (mojster) pa ekspresivni kvalifikator.

Zelo stare romanske izposojenke, izpričane že v praslovanščini in slovanščini, so deska, križ in lagev; slednji sta s stališča sodobnega slovenskega knjižnega jezika označeni kot narečni vzhodni.

Med zbranimi termini je moč zaslediti tudi nekaj tujk romanskega izvora; te so bile prek nemščine ali sodobnih evropskih jezikov sprejete v slovenski knjižni jezik, od tod pa v narečje. Izbor: amfora || 'a:nfora -e ž lončena posoda $z$ ozkim vratom, navadno dvema ročajema in koničastim dnom $\leftarrow$ knjǐ̌. sloven. amfora $\leftarrow$ nem. Amphore, frc. ampphore $\longleftarrow$ lat. amphora $\leftarrow$ gr. amphoréus, biskvit || bisk'vi:t -a m posušen, enkrat žgan lončarski izdelek, primeren za nadaljnjo obdelavo (žganje) $\leftarrow$ knjiž. sloven. biskvit (v narečju s pomenskim prenosom) $\leftarrow$ prek nem. Biskuit $\leftarrow$ frc. biscuit $\leftarrow$ lat. biscoctus, forma $\|$ 'foưurma -e ž določen videz lončarskega izdelka $\leftarrow$ knjiž. sloven. forma $\leftarrow$ prek nem. Form iz lat. forma, kaolin \|| kao'li:n -a m najčistejša bela porcelanska glina $\leftarrow$ knjiž. sloven. $\leftarrow$ frc. kaolin, keramika \| ke'ra:mika -e ž izdelki iz žgane gline $\leftarrow$ knjiž. sloven. $\leftarrow$ nem. Keramik $\leftarrow$ frc. céramique $\leftarrow$ gr. ta keramiká; gr. kéramos, kupola \|| 'kupola -e ž peč kopaste oblike, s tremi kurišč spodaj in 7-8 odduški na vrhu pod obokom, kot vir energije se uporablja les $\leftarrow$ knjiž. sloven. $\leftarrow$ it. cupola $\leftarrow$ poznolat. cūpola.

3.4 Madžarizmi so naslednji: bograč, falat, gomba, inaš, kulač, laboška, tepsija, tanjer; arandaš, bak, fotiv, rud, talige; slednja beseda je v SSKJ označena kot nar. prekmurska: bograč || 'bọgrač -a m trebušasta posoda z ročajem, pokrovom in tremi nogami, lahko tudi brez njih $\leftarrow$ madž. bogrács, falat || 'fålat fa'låta $\mathrm{m}$ kos, primerek lončarskega izdelka in kos sploh $\leftarrow$ madž. falat, gomba \| 'gọ:mba -e ž nastavek za luknjico za pitje vode na ročaju putre $\leftarrow$ madž. gomba, inaš || 'innaš -a m kdor se s praktičnim delom uči lončarske obrti; vajenec $\leftarrow$ madž. inas, kulač || 'kulač -a m ploščata, steklenici podobna okrogla lončena posoda s štirimi nogami za nošenje pijače $\leftarrow$ madž. kulacs, laboška || 'la:boška -e ž okrogla, nekoliko višja posoda z dvema ročajema, pokrovom, navadno tudi nogami za kuhanje, dušenje, praženje, cvrtje $\leftarrow$ madž. labas; prim. tudi madž. lab, tepsija || 'tepsija -e ž okrogel plitev pekač, katerega stena je podaljšani navzgor zavihani rob $\leftarrow$ madž. tepsi, tanjer $\|$ tan'jẹ:r -a tudi ta'lẹ:jr -a m krožnik $\leftarrow$ madž. tányér $\leftarrow$ nem. Teller; arandaš $\|$ aran'da:š -a m najemnik $\leftarrow$ madž. árendás, bak || 'båk -a m klepalnik $\leftarrow$ madž. bak $\leftarrow$ nem. Bock, fotiv || 'fọtif -va m krompir, ki se sam naseje, ostane $v$ zemlji od prejšnjega leta in naslednje leto zraste $\leftarrow$ 
madž. fattyú, rud $\|$ 'ru:t 'ru:da m drog na sprednjem delu voza, pluga, ob katerega se vprega žival; oje $\leftarrow$ madž. rud, telige $\|$ te'lige te'li:k ž mn. samokolnica $\leftarrow$ madž. taliga.

Najdemo še po eno izposojenko iz angleščine, v narečje sprejeto iz knjižnega jezika (kombajn), češčine - barva in hrvaščine - obrt, tri prek hrvaščine prevzete iz turščine in grščine - čutara, kalup, komad ter eno prek hrvaščine prevzeto iz španščine (silos).

V prekmurski narečni lončarski in poljedelski terminologiji se prepletajo izvirna slovanska poimenovanja izdelkov, orodij, pripomočkov, rastlin in delovnih postopkov s prevzetimi. Ta so večinoma germanskega izvora, prek nemščine so največkrat prevzeti tudi romanizmi, madžarskih prevzetih izrazov je malo. Prevzete besede so zvečina izposojenke (prim. Snoj 2006: 346), nekaj je tujk, ki so bile v narečje sprejete iz knjižnega jezika. Nekatere od prevzetih besed so bile sprejete v slovenski knjižni jezik, ostale pa so s stališča knjižnega jezika označene kot pogovorne, nižje pogovorne, narečne ali žargonske, veliko pa jih živi samo v narečju.

\section{Zaključek}

Razvoj prodira na vsa področja družbenega življenja, pri čemer ni izvzeto niti podeželsko okolje. Način življenja $\mathrm{v}$ času in prostoru se hitro spreminja, kar se odraža tudi v narečnem besediščnem sestavu. Z zamiranjem lončarske obrti izginja tudi staro poimenovalno besedje s področja lončarske dejavnosti. Prekmurski izrazi za lončarstvo, poljedelstvo in vse, kar je povezano s kmečkim življenjem, sicer še tvorijo bogat izvirnoslovanski substrat, ${ }^{5}$ vendar pa stara slovanska terminologija pri srednji generaciji govorcev hitro tone v pozabo (tako so npr. narečna poimenovanja za dele voza že skorajda izginila, saj je vprežno živino zamenjal traktor), mlajša generacija pa je sploh ne pozna več. Stoletja ustaljeno kmetijsko orodje so zamenjali različni stroji in pripomočki, skupaj z njimi pa se prevzemajo tudi poimenovanja zanje (npr. freza, kombajn, traktor). Nekatera stara imena, kot so brana, kosa, plug, se uporabljajo tudi za nove naprave, sicer pogosto poimenovane s slovenskimi ustreznicami, v narečje sprejetimi iz knjižnega jezika (npr. kosilnica, obračalnik, samonakladalka, sejalnik), dobro je še ohranjena stara terminologija za kmečka opravila, čeprav se je način obdelovanja spremenil.

Izsledki raziskave kažejo, da je bil stik z neindoevropskim madžarskim jezikom za prekmurščino manj usoden kot nemščina. Madžari so prevzemali slovanske besede z različnih področij dejavnosti, tudi poljedelske. Iz slovanski jezikov so npr. madž. cirok 'sirek', kukorica 'koruza', malna 'malina', murok 'mrkev', rend 'red, vrsta (sena)', ugorka 'kumara'.

\footnotetext{
${ }^{5}$ Izsledki raziskave kažejo, da je prevzetih približno $20 \%$ besed.
} 
Močnejše sledi v narečnem besedju je pustilo sobivanje z nemško jezikovno skupnostjo, prek nemščine so bili v panonsko leksiko največkrat sprejeti tudi romanizmi. Najstarejših germanskih in romanskih izposojenk se skorajda ne zavedamo več (npr. redkev; črešnja, deska, breskev), kot germanizme čutimo zlasti mlajše prevzete besede, ki so jih v panonski prostor prinesli rokodelski pomočniki, vojaki in romarji s svojih potovanj po srednji Evropi kot označevalce za različna orodja in poklice, od Nemcev pa smo sprejeli še kulturne rastline, tudi tiste romanskega izvora, in poimenovanja zanje.

Ugotovimo lahko, da je temeljno (staro) narečno poimenovalno besedje s področja lončarske in poljedelske dejavnosti slovansko. Škoda bi bilo, da bi potonilo v pozabo. Naša naloga je, da ga popišemo in tako ohranimo kot del slovenske kulturne dediščine, kak izviren starejši narečni strokovni izraz pa bo prav prišel tudi kot slovenska ustreznica tujim poimenovanjem, na kar je opozorila že Andreja Žele (1996: 337).

\section{OKRAJŠAVE}

Okrajšave jezikov so take kot v Snoj (2003): avstr. - avstrijsko, bav. - bavarsko, ben. - beneško, cslovan. - cerkvenoslovansko, frc. - francosko, gr. - starogrško, hrv. - hrvaško, ide. - indoevropsko, it. - italijansko, klas. - klasično, knjiž. - knjižno, lat. - latinsko, madž. - madžarsko, nar. - narečno, nem. - nemško, poznolat. - poznolatinsko, pslovan. - praslovansko, rom. - romansko, slovan. - slovansko, sloven. - slovensko, srlat. - srednjeveškolatinsko, srvnem. - srednjevisokonemško, star. - starejše, stvnem. - starovisokonemško, špan. - špansko, štaj. - štajersko

\section{LITERATURA}

France BEZLAJ, 1976-2007: Etimološki slovar slovenskega jezika. Ljubljana: Mladinska knjiga.

Janez BOGATAJ, 1989: Domače obrti na Slovenskem. Ljubljana: Državna založba Slovenije.

Rada COSSUTTA, 2002: Poljedelsko in vinogradniško izrazje v slovenski Istri. Koper: Zgodovinsko društvo za južno Primorsko in Znanstveno-raziskovalno središče RS.

Marc GREENBERG, 1993: Glasoslovni opis treh prekmurskih govorov. Slavistična revija 41/4, 465-487.

Marija JEŽ, 1997: Iz tkalskega izrazja na Pohorju. Slovensko naravoslovno-tehnično izrazje. Ur. Marjeta Humar. Ljubljana: ZRC SAZU. 209-216. 
Janko JURANČIČ: 1966: O leksiki v panonskih govorih. Panonski zbornik. Ur. Božidar Borko, Franc Zadravec. Murska Sobota: Pomurska založba. 31-41.

Mihaela KOLETNIK, 2008: Panonsko lončarsko in kmetijsko izrazje ter druge dialektološke razprave. Maribor: Mednarodna založba Oddelka za slovanske jezike in književnosti, Filozofska fakulteta. (Mednarodna knjižna zbirka Zora, 60).

Martina OROŽEN, 2003: Odvisnost narečnega besedišča in načina upovedovanja (izražanja) od spreminjajočega se načina življenja. Razvoj slovenske jezikoslovne misli. Maribor: Slavistično društvo Maribor. (Zora, 26). 310-318.

Petar SKOK, 1971-1973: Etimologijski rječnik hrvatskoga ili srpskoga jezika 1-3. Zagreb: JAZU.

Marko SNOJ, 1997, 2003: Slovenski etimološki slovar. Ljubljana: Mladinska knjiga. - - 2006: O tujkah in izposojenkah v slovenskem jeziku. Slavistična revija 54, 343-349.

Hildegard STRIEDTER TEMPS, 1963: Deutsche Lehnwörter im Slovenischen. Berlin: Osteuropa-Institut Berlin, Berlin-Dahlem.

Matej ŠEKLI, 2005: Odraz medjezikovnih stikov v poimenovanjih za vaške poklice in dejavnosti v nadiškem narečju. Večkulturnost $v$ slovenskem jeziku, literaturi in kulturi. Ur. Marko Stabej. Ljubljana: Center za slovenščino kot drugi/tuji jezik pri Oddelku za slovenistiko Filozofske fakultete. 176-181.

Jože TOPORIŠIČ, 1992: Enciklopedija slovenskega jezika. Ljubljana: Cankarjeva založba.

Peter WEISS, 2006: Besedje na kolesu v (slovenskem) narečnem slovarju z etimologijami. Diahronija in sinhronija v dialektoloških raziskavah. Ur. Mihaela Koletnik, Vera Smole. Maribor: Slavistično društvo Maribor. (Zora, 41). 328-335.

Zinka ZORKO, 1998: Narečne prvine v Ivanocyjevem Kalendarju Najszvetejsega szrca Jezusovega (1904-1906). Slovensko-madžarski jezikovni in književni stiki od Košiča do danes. Ur. István Nyomárkay in Stjepan Lukač. Budimpešta: Košičev sklad. 39-59.

Andreja ŽELE, 1996: Voz na Pivškem. Traditiones 25. Ljubljana: SAZU. 337-343.

\section{REFLECTION OF INTER-LINGUAL INTERLACING IN UPPER MURA TEXTS}

The Slovenian language, having developed over many centuries in a territory where three of the largest European language areas (Slavic, Germanic and Romance) come in contact, remained conservative because of its modest role before the fall of feudal society. However, it then began to develop into a modern European cultural language, within which Romance, German, Hungarian and general Slavic elements interlace with an inherited fund of fundamental words from ancient Slavic. In the Pannonian area, for historical reasons (Upper Mura, together with Upper Raba, was a component part 
of the Hungarian kingdom up to the 11th century and was separated from other Slavic regions), many archaisms were preserved. This study presents findings of research on original Slavic and non-autochthonous texts taken over from the Greek - Latin, German and Hungarian language areas, i.e., in the occupational (agriculture, pottery) terminology of the Upper Mura. It is established that (1) Upper Mura expressions from agriculture form an original Slavic substratum that is connected to the lives of farmers; (2) contact with the non- Indo-European Hungarian language had less impact on Upper Mura dialect than German (Hungarian experienced more of Slavic word influence); (3) stronger thaces in dialectal texts were left by cohabitation with the German language group; the oldest German loanwords in dialect texts came into the Upper Mura dialect from Old High German (Althochdeutsch) (from the 7th to the 11th century) and Middle High German (Mittelhochdeutsch) (muntelj, skedenj, uta; grunt, praha), while more recently adopted texts were spread especially in recent centuries (ripsa, rigolati). Through the medium of German, Romanisms were also frequently adopted (mašin, korbelj) in Pannonian lexcography. 